\title{
How Entrepreneurial Orientation Influences the Enhancement of Customer Knowledge Management Competence:
} \section{An Explorative Empirical Study}

\author{
Zhiyuan Li, Bo Wu, Yanhai Zhao \\ School of Management, Lanzhou University \\ Lanzhou, China \\ zhiyuanl@163.com, yhzhao@lzu.edu.cn
}

\begin{abstract}
Against the background where the entrepreneurial economy is replacing the managerial economy, the study on the entrepreneurial firms' knowledge management mechanism facing their customers in the wider sense is becoming the key to upgrade these firms' customer knowledge management competence. Thus, based on the a conceptual model construction of entrepreneurial firms' entrepreneurial orientation and their customer knowledge management competence, this paper studies, in an explorative manner, by way of an empirical study on firms with high entrepreneurial orientation, the correlation between the entrepreneurial orientation and customer knowledge management competence. The autonomy and the active competition of the entrepreneurial orientation manifest significant positive correlations to customer knowledge management competence, and to its process management and environment supporting competences. As a result, it is essential to the dynamic growth of customer knowledge management competence that the entrepreneurial firms should manage effectively the authorization as well as active competitive posture.
\end{abstract}

Keywords- entrepreneurial firms; entrepreneurial orientation; customer knowledge management competence; correlatio

\section{INTRODUCTION}

At present, the entrepreneurial researches are centered on two major entrepreneurial phenomena: the creation of new enterprises and corporate entrepreneurship. Since the 1990, companies like Apple have achieved great successes by way of entrepreneurial activities based on innovative opportunities and resource integration, which brings the corporate entrepreneurship (entrepreneurial firms) into academic focus. Through continuous positive interaction with various internal and external customers, these entrepreneurial firms have realized an effective embeddedness into the entrepreneurial network composed by customers in their wider sense (with internal customers such as employees and customers from different functional department, and with external customers such as suppliers, distributers, and consumers), and thus driven by entrepreneurial spirit, they have promoted, effectively, the circulation, diffusion and spreading of knowledge, which in turn, have promoted the organizational learning, and eventually promoted the rapid improvement of their performance(Zahra,1995)[1].
And a considerable amount of theoretical research and empirical studies have also demonstrated that, the key to entrepreneurial firms' successes is that these entrepreneurial firms are endowed with remarkable entrepreneurial orientation, and that those firms have constructed network relations with sufficient number of "resource gate" (Steier and Greenwood [2]). The study of Zahra Covin [3] has shown that the entrepreneurial orientation exerts significant influence of promotion on corporate performance, and this influence is increasing with the time. At the same time, Nonaka and Takeuchi (1995) [4] as well as Sveiby (1997)[5] have proved that, those firms with superior customer knowledge management performance have learning as their orientation, and they are likely to share knowledge, thus they can integrate the forces of different departments and functions to realize a common objective, which will lead to better corporate performance. Davenport and Klahr (1998)[6], for them, have pointed out that, an effective customer knowledge management will be beneficial to the improvement of tangible performance such as cost reduction as well as intangible performance such as customer satisfaction upgrading and their complaints reduction.

Although the existing studies have shown that the entrepreneurial orientation and customer knowledge management are all helpful to the improvement of corporate performance, but it is not clear that, if there is certain correlation between the entrepreneurial orientation as corporate spirit and attitude, and the customer knowledge management as corporate tactical actions. And if the correlation hypothesis is established, which entrepreneurial spirit dimensions of those firms with high entrepreneurial orientation will influence their customer knowledge management competence, and thus will improve their corporate performance? This paper, by way of the measurement and explorative study of Chinese firms' entrepreneurial orientation and customer knowledge management performance, thus, investigates the correlation and the influence mechanism between the two.

\section{LITERATURE REVIEW AND RESEARCH HYPOTHESES}

\section{A. Variable Definition}

1)Entrepreneurial Orientation (EO)

Ginsberg (1985) has introduced the definition of EO. For him, EO is defined as entrepreneurs' intentions and 
preferences in the dynamic entrepreneurial process [7], which is an "entrepreneurial attitude and spirit", that is to say, an autonomous, innovate, risk-taking and proactive action inclination facing with complicated market opportunities. Meanwhile, Miller and Friesen [8] proposed an EO measurement composed of three dimensions: innovativeness, proactive-ness and risk-taking. Covin and Slevin [9] developed a measurement of 9 items for EO and they also suggested several hypotheses for the correlation between EO and corporate performance. And Lumpkin et al. (2009) [10] have taken the three dimension construct of Covin-Slevin by adding two more dimensions: active competition and autonomy. Their final measurement is constituted of 5 dimensions and 22 items with.

\section{2)Customer Knowledge Management Competence} (CKMC)

Due to lack of customer knowledge extraction, sharing and utilization, a research report of Gartner Group proclaimed that, for $70 \%$ of all the firms, their customer relation management (CRM) practices have brought no influences on corporate performance [11]. Hence, customer knowledge management (CKM) has been noticed by academics as a key strategic resource. In 1997, Wayland and Cole [12] have first put forward the concepts of CKM. Then Alan Cooper (1998) [13] defined the CKM as the process where the firms, through advanced information technology and interactive exchange with customers, help customers to identify the problems and solutions to adapt to the surrounding environment, thus, a "well defined and customerized" marketing can be realized by way of powerful integration of customer demand process and corporate marketing process. Minna et al. (2005) [14] further defined CKMC as the "ability to integrate customer information and knowledge into organizational CRM process and business activities", and for them, with the premise of a the corporate culture, as a platform, which supports organizational learning and has customer orientation, the inter-functional synergy, organizational structure's support, cooperation with customers and supportive IT system determine the level of CKMC.

\section{B. Model Construction and Research Hypotheses}

\section{1)Variable Measurement}

The measurement of EO, according to the research of Lumpkin et al. (2009) [10], is composed of five dimensions: autonomy (AU), innovativeness (IN), proactive-ness (PR), risk-taking (RT) and active competition (AC), where, the autonomy refers to the degree where the employees have sufficient authorization, and teams and individuals have enough discretion to make vital decisions and to seek opportunities; the innovativeness is the level where the firm supports those creative activities such as new initiatives, new experiments and creative efforts with the purpose to develop new products and services; the proactive-ness means the degree where the firm identifies the opportunities and future market demands, and hen actively establish itself as the industrial leader; the risk-taking reflects the firm's inclination to support those projects with uncertain expected revenue, where the firm is willing to take the risks to grasp the opportunity and act in a courageous manner; the active competition indicates the aggressive intentions where the firm challenges the competition to enter the new markets, to improve its market position or to overcome the competitive threats. For the measurement of CKMC in this study, it is proposed that only by combining CKM process with the supporting environment can the CKMC be defined in an effective manner. Thus, the CKMC index system is constituted with two dimensions: process management competence (PMC) and environment supporting competence (ESC), where the former, CKM process management competence, refers to the process where the entrepreneurial firm exerts influences on the process of customer knowledge's acquirement, storage, sharing, utilization and innovation by advanced information technology so as to maximally extract, share and create customer knowledge's values, while the CKMC's environment supporting competence is composed of corporate culture, organizational structure, inter-functional synergy and IT system.

2)Relational Model and Hypotheses

In Menon's [15] study, it is considered that EO can promote the exchanges of creative thinking, can accelerate information circulation and product's upgrading. For Covin and Miles [16], it is suggested that, to seek new opportunities, those firms with high EO will continuously analyze and "scan" its own operation environment in order to make is easier for the firms to utilize knowledge to exploit market opportunities. In Tien's (2007) study [17], the positive correlation between EO and CKMC is demonstrated, and EO exerts positive influence on firm's ability to transform knowledge into new product and new processes. By these observations, the following relational model and relative hypotheses are established (See Fig.1).

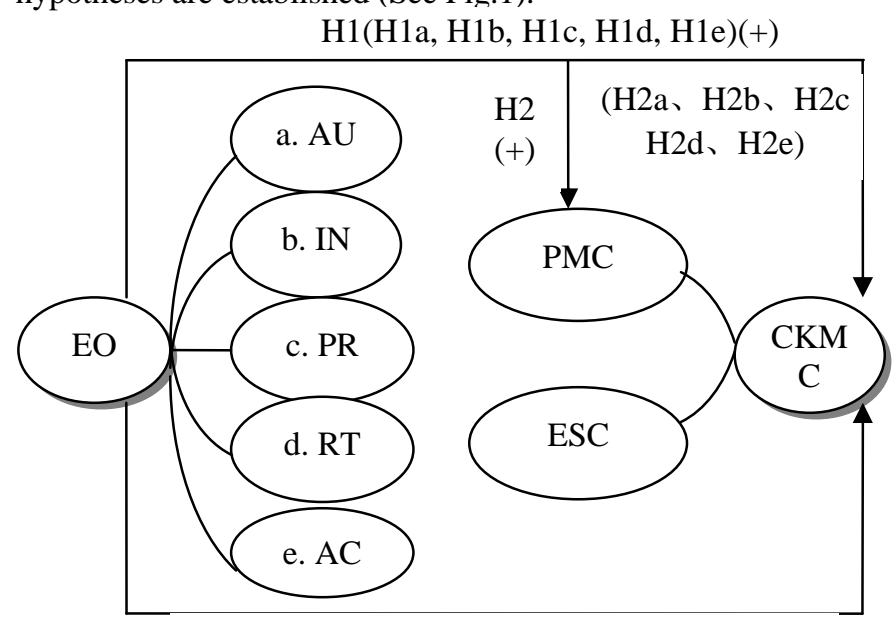

Н3(НЗа, Н3b, Н3c, Н3d, Н3е) (+)

Figure 1. Relational Model and Hypotheses of EO and CKMC

H1: High EO is in positive correlation to CKMC (EO's autonomy, innovativeness, proactive-ness, risk-taking and active competition are respectively in positive correlation to CKMC, that is, H1a ,H1b, H1c, H1d ,H1e) );

$\mathrm{H} 2$ : High EO is in positive correlation to CKM process management competence (PMC) (EO's autonomy, 
innovativeness, proactive-ness, risk-taking and active competition are respectively in positive correlation to CKM process management competence, that is, $\mathrm{H} 2 \mathrm{a}$,H2b, H2c, H2d ,H2e);

H3: High EO is in positive correlation to CKM environment supporting competence (EMC) (EO’s autonomy, innovativeness, proactive-ness, risk-taking and active competition are respectively in positive correlation to CKM environment supporting competence, that is, H3a ,H3b, H3c, H3d ,HЗe).

\section{RESEARCH DESIGN AND DATA ANALYSIS}

\section{A. Data Collection and Sample Characteristics}

From the basis of small sample survey test and by testing questionnaire's reliability and validity test, this paper finally selected the proven measurement of EO developed by Lumpkin et al. [10], which is composed of 5 dimensions and 22 items. In regard to CKMC measurement, an instrument of two dimensions with 34 items has been developed.

TABLE I. SAMPLE'S DISTRIBUTIONAL CHARACTERISTICS

\begin{tabular}{clll}
\hline Item & Characteristic & Frequency & Percentage\% \\
\hline \multirow{3}{*}{ Geographical } & Pearl Delta & 119 & 66.1 \\
Location & Yangtze Delta & 40 & 22.2 \\
& West & 7 & 3.9 \\
& Others & 14 & 7.8 \\
\hline & $0-1$ years & 25 & 13.9 \\
Existence & $1-5$ years & 90 & 50.0 \\
Duration & 5-10 years & 41 & 22.8 \\
& + 10 years & 21 & 11.7 \\
& missing & 3 & 1.7 \\
\hline \multirow{5}{*}{ Property } & State owned & 51 & 28.3 \\
Regime & Private & 58 & 32.2 \\
& Foreign capital & 41 & 22.8 \\
& Domestic capital & 8 & 4.4 \\
& Collective & 2 & 1.1 \\
& Others & 20 & 11.1 \\
\hline & Manufacturing & 54 & 30.0 \\
& Construction & 10 & 5.6 \\
& Distribution & 8 & 4.4 \\
& Service & 18 & 10.0 \\
Operating & Real Estate & 1 & 0.6 \\
& IT & 27 & 15.0 \\
& Finance & 29 & 16.1 \\
& Others & 27 & 15.0 \\
& Missing & 6 & 3.3 \\
\hline
\end{tabular}

All the two measurements apply the 7 point Likert scale. The research data has been collected from questionnaires conducted between October 2011 and February 2013 with high and middle managers in Guangzhou, Shenzhen, Shanghai and Lanzhou. In total, 256 questionnaires have been sent, and 221 questionnaires have been collected. After having eliminated those questionnaires with serious data deficiency, 180 valid questionnaires have been obtained with a valid return rate of $81.45 \%$. The distributional characteristics of the sample are summarized in the flowing aspects: geographical location, existence duration, property regime, and firm's operating sector (See Table I).

\section{B. Reliability and Validity Test}

By SPSS 19.0, all the variables of the relational model have undergone the reliability and validity tests, where the reliability test has been realized by Cronbach's a coefficients, and the validity tests has been conducted by KMO and Bartlett tests. The results are that, although the coefficient of EO's Cronbach's a is only 0.621, it still passes the minimum acceptable level of 0.5; while the coefficient of CKMC's Cronbach's a attains 0.949 , manifesting very good reliability. At the same time, all the KMO values of EO and CKMC are superior to 0.7 , thus proving relatively good validity, and showing that the results are suitable for factor analysis (See Table II).

TABLE II. VARIABLES’ RELIABILITY AND VALIDITY TESTS

\begin{tabular}{|c|c|c|c|c|c|}
\hline Variable & $\begin{array}{c}\text { KMO and } \\
\text { Bartlett } \\
\text { Tests } \\
\end{array}$ & Items & Mean & $\begin{array}{l}\text { Standard } \\
\text { Deviation }\end{array}$ & $\begin{array}{c}\text { Cronbach's } \\
\text { a }\end{array}$ \\
\hline \multirow{6}{*}{$\begin{array}{l}\text { AU } \\
\text { IN } \\
\text { PR } \\
\text { RT } \\
\text { AC }\end{array}$} & \multirow{6}{*}{$\begin{array}{l}\mathrm{KMO}=0.755 \\
\text { Bartlett }=231 \text {, } \\
\mathrm{P}<0.000\end{array}$} & 22 & 4.2957 & 0.57595 & \multirow{6}{*}{0.621} \\
\hline & & 8 & 4.5757 & 0.75389 & \\
\hline & & 5 & 3.8944 & 0.85833 & \\
\hline & & 4 & 3.6903 & 1.37246 & \\
\hline & & 4 & 4.8042 & 1.26272 & \\
\hline & & 1 & 4.4500 & 1.67223 & \\
\hline \multirow{3}{*}{$\begin{array}{r}\text { CKMC } \\
\text { PMC } \\
\text { ESC } \\
\end{array}$} & \multirow{3}{*}{$\begin{array}{l}\mathrm{KMO}=0.925 \\
\text { Bartlett=561, } \\
\mathrm{P}<0.000\end{array}$} & 34 & 4.9167 & 1.01725 & \multirow{3}{*}{0.949} \\
\hline & & 21 & 4.8878 & 1.07689 & \\
\hline & & 13 & 4.9615 & 1.12557 & \\
\hline
\end{tabular}

\section{Results Analysis}

By Table II, the mean of EO is 4.2957. Consequently, by current method, it is defined that, those firms whose EO mean is superior to the overall mean be firms with high EO. Thus, by further screening of the sample data, the firms with high EO are limited to 89. Then, a correlation analysis of all the variables in our model has been done. The results are summarized in the correlation coefficient matrix (Table IV). 
TABLE III. VARIABLES’ CORRELATION COEFFICIENT MatriX

Hypotheses
H1: High EO is in positive correlation to CKM
H1a: AU is in positive correlation to CKMC
H1b: IN is in positive correlation to CKMC
H1c: PR is in positive correlation to CKMC
H1d: RT is in positive correlation to CKMC
H1e: AC is in positive correlation to CKMC
H2: High EO is in positive correlation to PC
H2a: AU is in positive correlation to PC
H2b: IN is in positive correlation to PC
H2c: PR is in positive correlation to PC
H2d: RT is in positive correlation to PC
H2e: AC is in positive correlation to PC

H3: High EO is in positive correlation to ESC
Not supported

Supported

Supported
H3a: AC is in positive correlation to ESC

Supported

H3b: IN is in positive correlation to ESC

H3c: PR is in positive correlation to ESC

H3d: RT is in positive correlation to ESC

H3e: AC is in positive correlation to ESC

From Table IV, it can be observed that the Pearson correlation coefficient of EO and CKMC is 0.299**, i.e., at 0.01 level, EO is in significant positive correlation to CKMC. At the same time, EO's correlation to CKM process management competence and CKM environment supporting competence are respectively $0.245^{*}$ and $0.321^{* *}$, i.e. at 0.05 and 0.01 level, EO is in significant positive correlation to CKM process management competence and CKM environment supporting competence. Hence, the research hypotheses of $\mathrm{H} 1, \mathrm{H} 2$ and $\mathrm{H} 3$ in the relational model have been proven, and the other results of research hypotheses are shown in the table (Table III).
Not significant

Not significant

Not supported

Supported
Not supported

Supported

Supported

Supported

Not significant

Not supported

(1)

TABLE IV. Hypotheses’ Tests Results

\begin{tabular}{|c|c|c|c|c|c|c|c|c|c|}
\hline & $\mathbf{A U}$ & IN & PR & RT & AC & EO & PMC & ESC & $\begin{array}{r}\text { CK } \\
\text { MC }\end{array}$ \\
\hline $\mathbf{A U}$ & 1 & & & & & & & & \\
\hline IN & -0.045 & 1 & & & & & & & \\
\hline PR & -0.091 & 0.084 & 1 & & & & & & \\
\hline RT & $-.257 *$ & 0.013 & 0.04 & 1 & & & & & \\
\hline AC & $0.310^{* *}$ & 0.074 & $-.301 * *$ & -0.05 & 1 & & & & \\
\hline EO & $0.493^{* *}$ & $0.496^{* *}$ & $0.459 * *$ & $0.353^{* *}$ & $0.250^{*}$ & 1 & & & \\
\hline PMC & $0.307 * *$ & 0.136 & -0.027 & -0.125 & $0.326^{* *}$ & $0.245^{*}$ & 1 & & \\
\hline ESC & $0.481 * *$ & 0.048 & 0.005 & -0.121 & $0.276^{* *}$ & $0.321^{* *}$ & $0.694^{* *}$ & 1 & \\
\hline СКМC & $0.410^{* *}$ & 0.108 & -0.015 & -0.133 & $0.331^{* *}$ & $0.299 * *$ & $0.949 * *$ & $\begin{array}{l}0.88 \\
5^{* *} \\
\end{array}$ & 3 \\
\hline
\end{tabular}

\section{IV.DISCUSSION AND CONCLUSION}

By the empirical analyses of entrepreneurial firms with high EO, it is found that EO is in remarkably significant positive correlation to CKMC, and to its two dimensions of process management competence and environment supporting competence. The results have shown that, EO's autonomy and active competition dimensions are in positive correlation to CKMC and to its CKM process management ability and its CKM environment supporting ability, which indicates that, by way of resource reorganization, the value creation activities of these entrepreneurial firms such as product, technology, organizational innovation and strategic changes, require that those firms actively authorize their employees and teams so as to encourage them to seek new business activities in the deep embedded-ness of customer knowledge. In addition, these entrepreneurial firms should also break their behavior inertia. To confront the new business opportunities, they should take a more active competitive posture.
Meanwhile, the empirical study has not proven that all the dimensions of EO exert significant influences on CKMC. This can be explained by that, the 5 dimension measurement needs repeated tests and correction in China's management and cultural context. On the other hand, it is perhaps because the risk-taking intentions and proactive competitive strategies of these firms are more of autonomy, which cannot be transformed into firms' attention to customer knowledge. Furthermore, the fact that the innovativeness is not in correlation to CKM necessitates further study.

\section{ACKNOWLEDGMENT}

The authors of this paper thank Fundamental Research Funds for the Central Universities, Key Project (No. 12LZUJBWZD004) for their support. 


\section{REFERENCES}

[1] Zahra, S A, and Covin, J G. Contextual Influences on the Corporate Entrepreneurship-performance Relationship: A Longitudinal Analysis [J]. Journal of Business Venturing, 1995, 10(1) : 43- 58.

[2] Steier L, Greenwood R. Entrepreneurship and the Evolution of Angel Financial Networks [J. Organization Studies,2000,21( 1) : 163 - 192.

[3] Covin J G, Green K M, Slevin D P. Strategic Process Effects on the Entrepreneurial Orientation-Sales Growth Rate Relationship[J]. Entrepreneurship Theory and Practice, 2006.30(1):57-81.

[4] Nonaka I, Takeuchi H. The Knowledge-Creating Company. How Japanese Company Create the Dynamics of Innovation [M].New York: Oxford University Press, 1995:20-47.

[5] Sveiby K E. The New Organizational Wealth: Managing and Measuring Knowledge-based Assets[M].San Francisco Berrettkoehler Publishers,1997:55-74.

[6] Davenport T H, Klahr P. Managing Customer Support Knowledge [J].California Management Review, 1998, 40(3):195-208.

[7] Ginsberg A. Measuring Changes in Entrepreneurial Orientation Following Industry Deregulation [C]. Marietta, GA: Proceedings of the International Council of Small Business, 1985. 50-57.

[8] Miller, D., Friesen,P.. Strategy-Making and Environment: The Third Link[J]. Strategic Management Journal, 1983, 4:221-235.

[9] Covin J., Slevin D. Strategic Management of Small Firms in Hostile and Benign Environments[J]. Strategic Management Journal, 1989, (10):75-87.

[10] Lumpkin et al. Understanding and Measuring Autonomy: An Entrepreneurial Orientation Perspective [J]. Entrepreneurship Theory and Practice, 2009, 33 (1): 47-69.

[11] Group G. Strategic Planning [R], Research Note, 2001: 1-3.

[12] Wayland R, Cole P. Customer Connections: New Strategies for Growth [M]. Boston: Harvard Business School Press.1997.

[13] Alan Cooper. Customer Knowledge Management [J]. Pool Business and Marketing Strategy, 1998, 3-4: 256.

[14] Minna R, Aino H. CKMC: Towards a Theoretical Framework [C]. 38th Hawaii International Conference on System Science,2005, 240a.

[15] Menon A, Varadarajan P R. A Model of Marketing Knowledge Use within Finns[J].Journal of Marketing.1992,56:53-71.

[16] Covin J,M P Miles. Corporate Entrepreneurship and the Pursuit of Competitive Advantage[J]. Entrepreneurship: Theory and Practice,1999,23(3):47-63.

[17] Les Tien-Shang Lee, Sukoco, Badri Munir. The Effects of Entrepreneurial Orientation and Knowledge Management Capability on Organizational Effectiveness in Taiwan [J]. International Journal of Management, 2007,24(3) :549-572. 